\title{
1 The sea in Sumerian literature
}

\section{Lorenzo Verderame $^{1}$ (C)}

\author{
Received: 25 September 2019 / Accepted: 16 March 2020 \\ (c) Springer Nature B.V. 2020
}

\section{Abstract}

Surveying the references to the sea in Sumerian literature, this paper discusses the general idea that the sea is underrepresented in Mesopotamian cultures of the third millennium BCE. The common idea on Mesopotamian civilizations is that these were based on the rivers. However, recent research suggests the early Mesopotamian urban settlements of the third millennium BCE are on the ancient coast of the Persian Gulf and in the middle of lagoons or marshes. Coastal marsh cultures would not only have looked at the mainland, but also to the sea. Through a study of Sumerian literature and royal inscriptions, the historical relationship of the Mesopotamian cultures with the Persian Gulf is discussed. The image of the sea that emerges from literary sources reflects the changes that occurred in coastal region of southern Iraq during the third millennium BCE.

\section{Keywords Mesopotamia $\cdot$ Sea $\cdot$ Sumerian $\cdot$ Literature $\cdot$ Mythology $\cdot$ Persian gulf}

This article is the result of a paper presented at the workshop Waterscapes: Perspectives on hydrocultural landscapes in the Ancient Near East held at the 64th Rencontre Assyriologique Internationale (Innsbruck 2018). After my lecture, a colleague of mine criticized my historical reconstruction. He strongly maintained it was wrong, without being able, however, to specify in what I was wrong and in what he disagreed. I have taken his criticism very seriously. In the year between delivering the paper and submitting the present article, I went through all the primary sources and most of the secondary sources on the Persian Gulf in the third millennium BCE. In this article, I maintain the conclusions I reached in the paper. Primary sources from Mesopotamia are scanty and occasionally superinterpreted in secondary literature. General reconstructions of the relationship between Mesopotamia and the Persian Gulf are a matter of conjecture, which I leave to the specialists in the field. Before presenting my conclusions, I give an overview of the documentary sources mentioning the sea and the overseas lands without any further discussion, being this neither the focus of the paper presented at the workshop nor that of the present article. Furthermore, it should be reminded that most of the Mesopotamian third millennium BCE written sources are related to the central administration, and the non-state-controlled relationship with the Persian Gulf is absent or marginally represented in written records. My analysis is based on these sources and thus the reconstruction proposed refers only to state relationship with the Persian Gulf. Most of the Sumerian literature cited and discussed is available from the site of the Electronic Text Corpus of Sumerian Literature (= eTCSL; http://etcsl.orinst.ox.ac.uk). For the corpora of the royal inscriptions I refer to The Royal Inscriptions of Mesopotamia, Early Periods, here abbreviated RIME, i.e. RIME 2 = Frayne (1993). The chronology of third millennium BCE Mesopotamia is still subject to discussion. In this article I follow the chronology suggested by Sallaberger and Schrakamp (2015).

Lorenzo Verderame

lorenzo.verderame@uniroma1.it 


\section{Introduction}

${ }_{1 F L 01}{ }^{1}$ The extensive and exhaustive article of Heimpel (1987), despite the title ("The lower sea"), deals with 1FL02 the political and economic relationship with the overseas partners of Sumer in the Persian Gulf, rather than ${ }^{1 F L 03}$ with the sea.

${ }_{2 \mathrm{FL} 01}{ }^{2}$ «Im Zweistromland als einer typischen Flußtalkultur spielt das Meer - im Ganzen gesehen - keine her2FL02 vorragende Rolle» (Edzard 1993).

$3 \mathrm{FL}_{01}{ }^{3}$ In her dissertation, Pournelle (2003) questioned the traditional reconstruction of the environment of the 3FLo2 early Mesopotamian city-states. Through the analysis and discussion of archaeological and geological evi${ }^{3 F L 03}$ dence, she emphasises the role of the marshes. This work has been the base for successive studies by Pour${ }_{3 \mathrm{~F} L 05}$ nelle and by other scholars such as C. Hritz and T.J. Wilkinson. Archaeologists publishing the results of 3FLo6 their recent excavations in southern Mesopotamia (Abu Tbeirah, Tell Zurghul) have embraced the new perspective introduced by Pournelle. 


\section{The sea as a metaphor of vastness and awesomeness}

Often described as vast (dagal), the sea is used as a comparison for immenseness and terror. The interior of the Ekur, the temple of Enlil in Nippur, «is a wide (lit. empty) sea which knows no horizon» (Enlil A 44) and Eridu, the holy city of the god Enki, is said to stretch its shadow «until the midst of the sea» (Enki's journey to Nippur 53).

The angry sea with its towering waves recalls the feeling of stupor and terror that the awe of the divine should inspire to the worshipper. The god Enki «is awe-inspiring like the water of the sea» (Enki's journey to Nippur 83). The Netherworld god (Nergal, Meslamta'ea, Lugalerra), usually described as a fearsome figure, is compared to a sea with high waves and to an angry sea in two royal prayers dedicated to him by the Ur III king Ibbi-Su'en (2026-2003 BCE) and by the Isin king Šu-ilišu (1986-1977 BCE). ${ }^{4}$

Sea with high waves, you are imbued with terrible fearsomeness!

Mighty god who lives in the Land,

You are a great terror which covers heaven and earth!

(Ibbi-Su'en B A 11-13)

Nergal, angry sea, inspiring fearsome terror, whom no one knows how to confront, Youth whose rising is a tempest and a flood devastating the foreign lands, Nergal, dragon covered with gore, drinking the blood of living creatures! ( $\breve{S} u-i l i s ̌ u ~ A ~ 14-16)$

The perception of terror inspired by the sea is used to describe the temples and the cities as well.

The temple of Nungal is an «angry sea which mounts high, no one knows where its rising waves flow» (Nungal A 4). Eridu is a «rising sea without a rival» (Enki's journey to Nippur 54) and Ur is a «city which like the sea inspires awe!» (Nanna M 2). In one case the image of the fearsome sea is used to describe the army of the king Šulgi (2092-2045 BCE), «an irresistible onrush of water, a fearsome sea, ...» (Š ulgi $O$ A 23-24).

Feelings are occasionally compared to the overpowering sea. The healing goddess Ninisina helps the weak and the pious but persecutes and kills the wicked ones. In the royal prayer of the Isin king Iddin-Dagan (1975-1956 BCE), the rage of the goddess is described as a sea with towering waves which drowns the foe, her venomous bile covering the enemy like a high tide.

[Holy] Ninisina, [...],

Whose raging [heart] none can cool - is a heart made like the dusk; Whose angry [heart] no god can confront, Which like the sea, bringing a flood-wave, drowns the foe. Like the high tide, she pours spewed-out bile upon the enemy. (Iddin-Dagan D 34-38)

In the cylinders of Gudea (end of the XXII cent.), the heart (lit. interior) of the god Ningirsu is described through images of irresistible and destructive waters.

$4 \mathrm{FL} 01{ }^{4}$ See also the passage of a hymn to Nergal, «Like a rising frightening sea ..., with [your] kingship you 4FL02 inspire [terrifying fear]» (Nergal C 54-55). 
(O Ningirsu) your heart, ever rising as the sea,

Raising as a wave/wall,

Roaring like gushing waters,

Destroying cities like the flood.

...

The heart of the lord (Ningirsu) that rises like the sea,

That washes away like the Euphrates,

That hits like the flood,

That has overflowed with joy after inundating a land which is Enlil's enemy.

(Cylinders of Gudea A viii 23-26 and B x 19-23)

\section{The sea as a border and a limit}

The expression "from the lower sea to the upper sea" gives the two extremes of the "known" world and indicates totality in the royal inscriptions, together with the ruler's epithets "king of totality" and "king of the four regions" (see below). In the literature, this sentence is found twice, both referring to control over regions in the periphery and the flow of tributes. In a tigi hymn to Enki for the king of Isin Ur-Ninurta (1925-1898 BCE), the god is asked to «present him with weighty tribute from the upper and the lower seas» so that the ruler can «bring it into the shining Ekur», the temple of Enlil, head of the pantheon and patron of kingship (Ur-Ninurta B 41-42).

A passage from a hymn dedicated to Dumuzi and Inanna is more detailed. The divine couple should grant the symbols of kingship (the staff and the crook) to the ruler, «from the rising of the sun to the setting of the sun, from the south to the north, from the upper sea to the lower sea, from where the halub tree grows to where the eren tree grows, over all Sumer and Agade» (Dumuzi and Inanna Dl 42-46).

In literature, the sea, i.e. the Persian Gulf, remains the lower border of the world, but the mountain is often the opposite extreme. The limits determined by the lower sea - upper sea area in the "from the lower sea to the upper sea" expression is substituted by an area bounded by sea - mountain. 5

(Enlil) raised his eyes southwards and there was the wide sea;

He raised his eyes northwards and there was the mountain of the scent of eren.

Enlil piled up the barley, gave it to the Mountain.

(How grain came to Sumer 5-7)

In the literary account of kings' military successes, the sea and the mountain are the limits of the world and thus of their rulership. In the epic account of the struggle between Uruk and Aratta (a mythical city in the middle of the Iranian plateau), Ur-ĝirnuna, a sorcerer of Hamazi, offers his services to the king of Aratta, declaring «I will make (the territories) from below to above, from the sea to the eren mountain, from above to the mountain of the scent of eren, submit to my great army» (Enmerkar and Esuhgirana 146-147 // 159-160). Going from a mythic ruler to a historical one, the Ur III king Šulgi boasts about his campaigning, stating «I carried the weapon across the sea to the south, I jerked up the hostile

5FL01 ${ }^{5}$ For different aspects of the kur, a Sumerian term for mountain, foreign country, and Netherworld, see 5FL02 Katz (2003) and Verderame (2011) and, associated with the sea, Verderame (2020b). 
land of Elam as if it were grass by a gateway, how in the north I the people like grain» (Šulgi E 23-25).

After the fall of the Ur III dynasty (ca. 2000 BCE), political power in Mesopotamia fragments. Despite episodic military successes outside Mesopotamia, the city-states of Isin, Larsa, and then Babylon, fight to control the region. The rulers barely maintain the ambitious titles and claims of their predecessors. In royal inscriptions, the sentence "from the lower sea to the upper sea" and the titles "king of totality" and "king of the four regions" are more carefully employed. In a hymn to Haya for Rim-Sin (1822-1763 $\mathrm{BCE})$, king of Larsa, there is no declaration about the ruler's control over the world, but the Mesopotamian god Haya still «receives the tribute for the gods, the yield of the Mountain and the distant sea» (Rim-Sin B 15). Even for Samsu-Iluna (1749-1712 BCE), successor of Hammu-rabi of Babylon, the borders of his rulership are reduced. He is not the lord of all lands, but only of his land, which extends «from the banks of the Tigris and the banks of the Euphrates, to the shores of the sea» (Samsu-iluna F B 5).

Finally, the apocryphal letters attributed to the Ur III kings offer further evidence to the geographical functions of the sea.

My lord, you have given me instructions about every matter, from the sea and the land of Dilmun, from (var.: to) the salty waters and the borders of the land of the Martu, to (var.: from) the border of Simurrum and the territory of Subir.

\section{(Letter from Aradĝ $\mathrm{u}$ to Šulgi about irrigation work 3-6)}

Enlil, my lord, has ... the shepherdship of the land. Enlil has told me to bring before Ninisina the cities, deities and troops of the bank of the Tigris, the bank of the Euphrates, the bank of the Ab-gal and the bank of the Me-Enlila watercourses, from the territory of Hamazi to the sea of Magan. (Letter from Puzur-Šulgi to Ibbi-Suen about Išbi-Erra's claim on Isin 7-14)

\section{The overseas countries}

In the historical period, the sea is a mythical as well as a real border for the Mesopotamians. Over the sea, on far shores, are lands that were once of greater importance, but whose relationship with Mesopotamia fade away during the third millennium BCE, if we rely on the scarcity of archaeological and epigraphic evidence. ${ }^{6}$

Three geographical entities emerge from the Mesopotamian written sources - literary and otherwise - of the second half of the third millennium BCE. They go under the name of Dilmun, Magan, and Meluhha, ${ }^{7}$ and they correspond approximately to the regions around Bahrain, Oman, and the coastal area between Pakistan and northern India (Heimpel 1987; Maekawa and Mori 2011; Laursen and Steinkeller 2017). In literature, their status swings from myth to history. They are usually mentioned in relation with the export of precious stones, wood, and exotic animals. ${ }^{8}$

\footnotetext{
6FL01 ${ }^{6}$ See below and fn. 32.

7FL01 ${ }^{7}$ Other lands are occasionally located on the edge of the sea. For example, the Lament for Sumer and Ur (1. 7FL0236) mentions the Mount Zabu, while a hymn of Išbi-Erra (2019-1987 BCE) mentions Bašime and another ${ }^{7 F L} 03$ place whose name is lost (Išbi-Erra B C 4, 10).

$8 \mathrm{FL} 01{ }^{8}$ For a detailed analysis of these goods see Heimpel (1987); see also Pettinato (1972) and Kramer (1977).
} 
Let the lands of Meluhha, Magan and Dilmun

Look upon me, upon Enki.

Let the Dilmun boats be loaded (?) with timber.

Let the Magan boats ... the horizon.

Let the magilum boats of Meluhha exchange gold and silver

And bring them to Nippur for Enlil, [king] of all the lands.

(Enki and the world order 124-130)

May the land of Meluhha load precious desirable cornelian,

Meš wood of Magan and the best $a b b a$ wood

Into large ships for you.

May the land of Marhaši ... you precious stones and ....

May the land of Magan offer you strong, powerful copper,

Dolerite, $u$ stone and šumin stone.

(Enki and Ninhursaĝa 49C-L)

Magan and Meluhha loaded wood from their mountains upon their shoulders for him. ${ }^{9}$

(Cylinders of Gudea A xv 8)

Among the three, Dilmun is the most prestigious (Marchesi 2014). The relationship is so close that Dilmun's status goes far beyond the historical reality. Dilmun becomes part of Mesopotamian culture and even enters the mythical sphere. In the Sumerian narrative of the deluge, after surviving the flood, Ziusudra, the Sumerian Noah, is relegated in a land across the sea, Dilmun.

At that time, Ziusudra was the king -

To watch over the animals and the seed of mankind,

They settled him in an overseas country, in the land Dilmun, where the sun rises.

(The Flood Story E 9-11)

The role of Dilmun in Mesopotamian cultures of the third millennium BCE is so relevant that a Sumerian myth describes its foundation. The god Enki gives Dilmun to her spouse (Ninsikila/Ninhursaga), though the site is still in its primordial state. The god transforms brackish water in fresh water sources, an act that makes Dilmun a proper urban settlement, a "city" (Verderame 2011):

The waters rose up from it into her great basins.

Her city drank water aplenty from them.

Dilmun drank water aplenty from them.

Her pools of salt water indeed became (pools) of fresh water.

Her fields, meadows and furrows indeed produced grain for her.

Her city indeed became an emporium on the quay for the Land.

Dilmun indeed became an emporium on the quay for the Land.

At that moment, on that day, and under that sun, so it indeed happened.

(Enki and Ninhursaĝa 55-62)

9FL01 ${ }^{9}$ The passage has been translated alternatively as «Magan and Meluhha came in submission from their 9FL02 mountain»; see fn. 33 . 
The strategic role of Dilmun is highlighted by the end of the above-mentioned paragraph. Protruding in the Gulf, the Bahrain peninsula is the gate to Mesopotamia. Dilmun is the "emporium" of Sumer, the place from which precious and exotic goods coming from Magan, Meluhha, and other overseas regions reach the quays of Southern Mesopotamian cities. ${ }^{10}$ The antiquity and prestige of Dilmun in Mesopotamia's relationship with the Persian Gulf is substantiated by non-literary sources of the earlier periods, where only Dilmun is mentioned among the overseas regions. Magan and Meluhha appear with the founder of the Agade dynasty, Sargon (ca. 2300 BCE), who claims in his inscriptions to have made Dilmun, Magan, and Meluhha boats moor at the quay of Agade. It is during the Agade period that Magan begins its ascent and possibly reaches a leading role in the Gulf, according to archaeological and epigraphic evidences (Laursen and Steinkeller 2017).

\section{The yield of the sea}

Literary passages dwell on the abundance or yield (he $\mathrm{h}_{2}$-gal ${ }_{2}$, ma-dam) of the sea. ${ }^{11}$ After creating Dilmun, among the blessings pronounced by Enki on the behalf of Ninsikila is that «the wide sea [may bear to you] its yield» (Enki and Ninhursaĝ $a$ 49P). A similar blessing is kept in the final passages of an apocryphal composition describing the destruction of Southern Mesopotamian cities at the end of the Ur III dynasty (ca. 2000 BCE): the future of reconstruction implies «that the sea should bear yield by itself» (The lamentation for Sumer and $U r$ 508). A reference to the yield of the sea is contained in the above-mentioned passage of Rim-Sin's hymn to Haia (Rim-Sin B 15). In a hymn of the same king, the moon god Nanna is asked to provide «from the sea, the wide sea, from the standing reservoirs, an unending bearing (of yield) for your kingship» (Rim-Sin G 35-36). In the long list of things that Enlil makes happen, it is stated that without the god «the sea would not bear by itself its heavy treasure» (Enlil A 117). ${ }^{12}$

The frequent mention of the yield of the sea may appear quite surprising in a tradition where references to the sea are lacking and, even in administrative documents, fishing is mostly related to rivers. On the other hand, recent archaeological investigations of early settlements of Southern Mesopotamia have shown how the economy and diet of coastal sites heavily depend on marsh and sea products. The literary passages highlight another interesting aspect of the perception of the sea in Mesopotamian cultures. The sea, in fact, is said to produce by itself the yield, and moreover the verb employed is "to give birth" $\left(\mathrm{u}_{3}-\mathrm{tu}\right) .{ }^{13}$ Thus, the sea, often conceived as a female element, "gives birth" by herself to the abundant product. ${ }^{14}$

\footnotetext{
$10 \mathrm{FL} 01{ }^{10}$ In the sources of the Syrian city of Ebla, there is only one reference to Dilmun as a toponym (ARET V 7 10FL02 rev. IV 1). On the so-called mina of "Dilmun" at Ebla see Maiocchi (2005).

$11 \mathrm{FL} 01{ }^{11}$ For the Akkadian term miširtu "produce of the river or the sea", see Chicago Assyrian Dictionary $\mathrm{M}_{2}$ $11 \mathrm{FL} 02$ 123-125.

12FL01 ${ }^{12}$ Temple Hymns 305 mentions «the abundance of the midst of the sea» referred to the Ebursigsig, the tem${ }_{12 F L 02}$ ple of the god Šara in Umma. For fish "growing" see also the passage of Nanše B 10-11 discussed below.

${ }_{13 \mathrm{FL} 01}{ }^{13}$ See also the passage from Winter and Summer 31, cited below.

14FL01 ${ }^{14}$ See also the passage from the hymn to Nanše (Nanše B) discussed below, where fish are said to grow for 14FL02 the goddess. For the engendering of the sea and other cosmic regions see Verderame (2020b). This perspec$14 \mathrm{FL} 03$ tive may oppose the products of the sea to that of agriculture, which instead needs "fecundation" and cul${ }_{14 \mathrm{FL} 05}$ tivation, and may also explain the lack of reference to sea products in central administration records: while ${ }_{14 \mathrm{FL} 06}$ agriculture is the result of state-controlled work, sea products are perceived as something spontaneous and alien.
} 


\section{The midst of the sea}

241 The midst of the sea ( $\mathrm{ab}$-ša $\left.\mathrm{a}_{3}\right)$ is mentioned in several literary passages. ${ }^{15}$ The general meaning is that of a remote place which, on a horizontal plane, is a remote point, far from the seashore, and, on a vertical plane, it means the depth of the sea. Thus, large $u$ birds come far away from the midst of the sea (Copper and Silver 82). Frequent is the reference to the shadow extending out into the midst of the sea. It may be the case of the shadow of a god, meaning the extension of the god's power, as in an Old Akkadian incantation from Susa $(M D P 14,91)$, where Enki's shadow «stretches out into the midst of the sea». Or it may be the case of a temple, referring to the hugeness of the building. The shadow of the Ekišnugal, the temple of Nanna at Ur, «extends out into the midst of the sea» (Nanna G B 12) and the temple of the god NinMARki in Guabba is called «House which stretches over the midst of the sea» $\left(e_{2}-a b-s a_{3}-\right.$ ga-la $\left._{2}\right){ }^{16}$

Alternatively, the midst of the sea in the sense of abyss is a dark place, inaccessible to light and sight. «Fish light up the interior of the sea like fires» (Nanše B B 3), but the rays of the sun do not illuminate it and the sight of the gods cannot scrutinise its interior ( $\ll$ My brother, the midst of the sea ..... my eyes», Utu F 32). ${ }^{17}$ In this sense and in the light of the engendering of the sea above discussed, the relationship of the $a b z u$ and the womb must be noted. ${ }^{18}$

\section{Other references to the sea}

In the following section, other isolated and unsystematised references to the sea are discussed.

In the Sumerian King List, at the end of his kingdom, the ruler «Meš-ki-aĝ-gašer entered the sea and descended to the Kur» (Sumerian King List 99-101), an expression that clearly refers to dying. The relationship of the sea with the Netherworld is not diffused in Mesopotamia. All located below the earth, the domain of the god Enki, the underground sweet waters (abzu), and the Netherworld occasionally overlap..$^{19}$ The same god Enki is the protagonist of a myth which is briefly mentioned at the beginning of Gilgamers, Enkidu, and the Netherworld and relates him to the Kur. In the later Akkadian tradition, a "river" of

\footnotetext{
15FL 01 For the "midst of the sea" see also fn. 12.

16FL01 ${ }^{16}$ It should be noted, however, that the two temples belong to gods related to the marsh and the sea (see 16FL02 below). Furthermore, they are settled in cities which are on the edge of the lagoon or directly on the sea${ }^{16 F L 03}$ shore. Guabba means literally "shore of the sea"; for this site see the recent synthesis in Laursen and Stein${ }^{16 \mathrm{FL} 04}$ keller (2017).

17FL01 ${ }^{17}$ Compare the description of the sweet water abyss, seat of the god Enki: «the deep engur, the subterra17FL02 nean water, the place the inside of which no god knows» (Enki and Ninmah 13).

${ }_{18 F L 01}{ }^{18}$ See, for example, the beginning of the Old Babylonian childbirth incantations YOS 11, 86, which begins $18 \mathrm{FL} 02$ «In the fluid of the coitus, the bones are created. In the flesh of tissues, the homunculus is created. In the ${ }^{18 F L 03}$ water of the fierce and frightening ocean, in the water of the distant sea, the place where the child has his ${ }_{18 \mathrm{FL} 04}$ hand bounded, whose interior is not illuminated by the sun», and CUSAS 32, 28a, «In the fluid of the coitus ${ }_{18 \mathrm{FL} 06}^{18 \mathrm{~F} 05}$ the [...] was cr[eated]. In the remote water of the Apsû, in the water of the ocean, the wide sea, (in) a place 18 FL07 whose interior nobody knows, the baby, his hands are bound, his eyes are covered». For these and other aspects see below and Verderame (2020b).

19FL $01{ }^{19}$ For the Kur see fn. 5 and, for its geography, Katz (2003) and Verderame (2014).
} 
salty water encircles the world, ${ }^{20}$ as depicted in the Babylonian Map of the World, a drawing on a clay tablet kept in the British Museum (BM 92687) and dated around the mid of the first millennium BCE. The world is encircled by a bitter water river. This "salty" river is the ocean that separates the Land of the Living from that of the Dead. In The Epic of Gilgameš, the king of Uruk reaches the hero of the deluge, Uta-napišti, who had been relegated to an island across the ocean. ${ }^{21}$ In order to do so, Gilgameš crosses the ocean and its Waters of Death by sailing with Ur-Šanabi, all elements recalling the dead souls' crossing a water border with the infernal ferryman (Verderame 2014).

The powerful flowing of the waters of the Tigris in the sea is used as a metaphor for impressive and massive phenomena. ${ }^{22}$ A passage of the Lugal-e describes the primordial situation when the river waters did not yet flow into the sea: «(At that time,) the Tigris did not bring to heaven its flowing in its fullness. Its mouth did not [finish] in the sea, it did not [carry] sweet water» (Lugal-e 340-341). In The Curse of Agade, Inanna opens the city-gates and makes «Sumer bring its own possessions upstream by boats»; her action is compared to the Tigris flowing into the sea (The Curse of Agade 43-45).

In the debate between Winter and Summer, the former, besides regulating the floods and the flowing of the two rivers, «shaped lagoons in the sea and made the sea generate fishes and birds by itself» (Winter and Summer 30-31).

Both in Heron and Turtle and Bird and Fish, the eggs from the bird's nest are smashed into the sea by the deceitful neighbour (the turtle or the fish).

The storm god Iškur is said to «howl over the sea» (Sin-iddinam E 15); the verb "to howl" $\left(\mathrm{sa}_{4}\right)$ describes the sound of the marshes as well (Verderame 2020a).

Two passages mention the light reverberating over the water of the sea. Concerning the boat of the goddess Nanše, its gold canopy sparkles and its cabin shines like the moonlight on the sea (Nanše B B15-18). In a hymn to Ninurta, the god is said to cover «the edge of the sea with rays of light» (Ninurta G 134-135). The composition continues with a long passage calling Ninurta as Ena-tum or Enakam in relation with precious stones and foreign land from where they come from: gold of Harali, cornelian and lapis lazuli from Meluhha, dušia stone from Marhaši, silver of "fifteen cities", copper and tin from Magan, bronze from [...], silver from Dilmun, etc. (Ninurta G 136-154).

Finally, the sea is mentioned in three proverbs. The first and most famous is that of the fox which, after having urinated into the sea, says «The depths of the sea are my urine!» (Proverbs collection 2+6 2.67). The second and the third refer to fish of the sea (Proverbs collection $2+62 . \mathrm{d} 13$ and $11 \mathrm{C} 15)$.

\section{The sea in the Sumerian pantheon}

In addition to the few references to the sea in the Sumerian literary tradition, we note its lack of relevance in religious thought, and the absence of a distinct god or goddess of the sea.

\footnotetext{
20FL01 ${ }^{20}$ For the "salty" river of the Babylonian Map of the World and the Netherworld elements in Gilgameš" 20FL02 travel in The Epic of Gilgameš as well as the river/sea as the border between the Land of the Living and that ${ }^{20 \mathrm{FL} 03}$ of the Dead see Horowitz (1998) and Verderame (2014), with previous bibliography.

$21 \mathrm{FL} 01{ }^{21}$ In the Sumerian version of the deluge story, Ziusudra is relegated in Dilmun, "an overseas country"; see 21 FL02 above.

22FL ${ }^{22}$ See also the passage of Šulgi O A 23-24 discussed above.
} 
In the Akkadian tradition, the divinised sea, Tiamat, plays a minor role. In the Babylonian cosmogony, kept in the Poem of the Creation (Enüma elǐs), everything did originate from the female salty water by melting with the male sweet water. The two elements are personified by Tiamat and Apsû. ${ }^{23}$ They may be considered two titans, pre-divine beings whose role is relegated to the primordial time. Tiamat and Apsû are the first of a series of couples from which the gods were finally created. ${ }^{24}$ Upon their deaths, their bodies are transformed into cosmic regions. In the Poem of the Creation, $\mathrm{Ea}^{25}$ kills Apsû and transforms it in his abode, while Marduk slaughters Tiamat and from her body creates the world.

It should be noted that the Sumerian name of the Abzu, the watery cosmic region, abode and domain of the god Enki, is always written through two signs, ZU:AB, the latter referring possibly to the "sea" (ab). A passage from the Sumerian myth Enki and the World Order substantiates the connection of the Abzu with the sea. In fact, Enki establishes his abode in the sea.

The lord established a shrine - it is a holy shrine, whose interior is skilfully built. In the sea, he established a shrine - it is a holy shrine, whose interior is skilfully built.

$\cdots$

... a terrifying sea - it is a rising wave, its aura is fearsome.

(Enki and the World Order 285-286, 290)

Besides being the god of the sweet underground waters, Enki is somehow connected to the sea and most of the literary passages mentioning the sea refer to him or his domains. Enki's holy city, Eridu, lies on the seashore or on a lagoon directly connected to the sea. Eridu is a rising sea without a rival (Enki's journey to Nippur 54) and its shadow stretches far away on the sea (Enki's journey to Nippur 53). A far echo of the relationship among the god, its city and the sea are found in the Akkadian myth of Adapa, where the wise citizen of Eridu, protégé of Ea, sails into the wide sea for the daily fish for the cult of Eridu. ${ }^{26}$ In Enki and the World Order, however, Enki gives patronage over the sea to another goddess, Nanše.

Her who ride [the makurru boat?] in the holy shrine,

Who establishes sexual intercourse .......,

Who ...... over the enormous high flood of the subterranean waters,

The terrifying waves, the tide of the sea ......,

Who comes forth from the ......,

The mistress of Sirara, ... fish ... - Nanše,

Over the waters of the sea, a place of vastness,

Enki appointed (her).

(Enki and the World Order 301-308)

\footnotetext{
23FL01 ${ }^{23}$ Tiamat is related to the Akkadian term for "sea"(tiāmtu); Apsû is the Akkadian form of the Sumerian 23FL02 Abzu, the underground sweet waters.

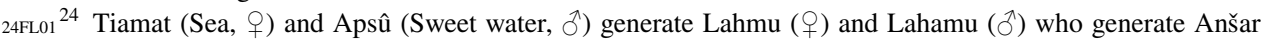
24FL02 (Sky, §3) and Kišar (Earth, ㅇ); Poem of the Creation I 1-13, see Verderame (2020b).

25FL01 ${ }^{25} \mathrm{Ea}$ is the Akkadian counterpart of the Sumerian god Enki.

${ }_{26 \mathrm{FL} 01}^{26}$ For the relationship of Eridu with the sea according to archaeological and textual evidence, see the 26FL02 results of the excavation of the site by Safar, Mustafa and Lloyd (1981), where clay models of sail boats ${ }^{26 \mathrm{FL} 03}$ have been found. In 2019 an international team (Italian, French, Iraqi) has returned to the excavation of ${ }^{26 \mathrm{FL} 04}$ Eridu and will undoubtedly provide relevant new data on the site's environment.
} 
The Temple Hymns composition describes Nanše as «a great storm, a mighty flood, born on the shore of the sea, who laughs on the foam of the sea, who plays on [the water] of the waves» (Temple Hymns 276-279). However, Nanše is properly a goddess of the lagoon and the marshes. ${ }^{27}$ Her temple (Sirara) and her city (Nina/Niĝin) lies on the marshes and Nanše is exalted as the mistress of fishes and birds that prosper in the marshes under her protection. The composition known as Nanše and the birds (Nanše C) lists in detail the birds that thrive thanks to Nanše, particularly those who make their nest in the reed bed. The relationship of Nanše with the fish and the sea is the focus of another hymn unfortunately fragmentary (Naň̌e B):

A fish is held in her hand as a staff [...]

Fishes are put on her feet as sandals [...]

Fishes light up the interior of the sea like fires [...]

Fishes play on instruments for her like sur priests.

Fishes bellow for her like oxen.

Fishes wrap around her body as a $b a$ garment.

The runner-fish $\left(\mathrm{kas}_{4}-\mathrm{kaš}_{4}\right)$ runs $\left(\mathrm{kaš}_{4}\right)$ to her.

The gurgur fish thicken $\left(\right.$ gur $_{4}$-gur $_{4}$ ) the sea for her.

The flash-fish (ĝir) makes the sea sparkle (gir) for her.

She spreads out fish spawn in sheaves,

So that fish will grow for her in the sea.

Fishes fly around for her like swallows.

"I, the lady, will ride on my makurru boat, I will ride home.

I will ride on the prow of the boat, I will ride home."

(The boat's) canopy of gold and fragrant eren wood

Sparkles for her on the sea;

Its cabin like a merry moonlight

Illuminates the sea.

"My husband is the enku of the sea,

Nindara is the enku of the sea."

(Nanše B B 1-20)

If Nanše C celebrates the birds, Nanše B praises the goddess' patronage over the fish of the sea. She is responsible for their growth (Nanše B B 10-11). In Enki and the World Order, Enki gives Nanše the office of inspector of the fish of the sea (enku), a prerogative that she shares with her husband, Nindara, and her daughter, NinMARki.

(Enlil said:) "Nanše, the powerful lady, who rests her feet on the holy goose, Is to be the enku of the sea.

Fish which are delicious things and birds which are sweet things,

She will provide to Nippur for her father Enlil”.

(Enki and the World Order 418-421)

Nanše's husband is called «the lord of the holy sea, the francolin (dar), Nindara, the king of Lagaš» (Hendursaĝa A A 25-26) and Nanše's statement about Nindara's function as enku closes the above-mentioned hymn of the goddess (Nanše B B 19-20).

27FL 01 The hymn Nanše A describes all the prerogatives of the goddess, among which we find no references to 27FL02 the sea or the marshes. For a general overview on Nanše see Heimpel (1998). 
NinMARki, first-born daughter (dumu-saĝ) of Nanše, is the goddess of the seashore city of Guabba and her temple is called "House which stretches over the midst of the sea". ${ }^{28}$ A passage from the Temple Hymns recalls the fact that she holds the title of enku "like her father".

$\mathrm{O}$ "House which stretches over the midst of the sea", built in a holy place,

Guabba, your interior gives birth to everything ${ }^{29}$ and is a well-established storehouse.

Born in $\ldots, \ldots$ in the flood of the sea,

Like her father ... inspector (enku) of the pure sea.

[In Guabba(?)] holy NinMARki

Has established her house in your [...] and taken her seat upon your (Guabba's) dais. (Temple Hymns 283-284, 289-292)

Nanše, patron of the fish, is the protective goddess of the fishermen as well, as stated in a fishing song which ends «(O fish, ) [Nanše], the mistress of the fishermen, will be delighted with you» (The home of the fish $\mathrm{C}$ 16-17). This prerogative is shared with another god of Nanše's circle, Hendursaĝa, who is celebrated as rescuer of mariners in a hymn dedicated to him $^{30}$ :

The god who has looked upon him will give him great strength.

The gusting south wind in the marshes will not sink (the pious') boat thanks to him (Hendursaĝa);

He will complete (his journey) as if he were in a carriage.

On the water of the sea - its vast place, the strong breaker does not touch him.

(Hendursâga A C 25-28)

\section{The sea in the historical setting of third millennium BCE Mesopotamia}

The lack of relevance of the sea in the Sumerian literature and religion is related to the historical development of the region (Nissen 1988; Liverani 2013). Early urban states arise in South Mesopotamia in the area lately identified as Sumer at the end of the fourth millennium BCE. Placed on the coast, amid marshes and lagoons, or with access to the sea through watercourses, these early city-states lie between the interior of the Mesopotamian plain and the Persian Gulf. They are part of an economic and cultural network that connects the settlements on the coasts of the Persian Gulf and the Indian Ocean (Potts 2009; Steinkeller 2013; Barjamovic 2018). Archaeological evidence from the Gulf sites, rather than from Mesopotamia, documents these relationships in the early phases (Laursen and Steinkeller 2017). Many domesticated vegetal and animal species which become central for the economy and the culture of Mesopotamia are imported from the Persian Gulf, particularly from the Indian peninsula (Potts 1997).

From the mid third millennium BCE the relationship of Mesopotamia with the Persian

${ }_{28 \mathrm{FL} 01}{ }^{28}$ For Guabba see fn. 16; for the "House which stretches over the midst of the sea" $\left(\mathrm{e}_{2}\right.$-ab-ša 3 -ga-la $\left.{ }_{2}\right)$ see 28FL02 George (1993).

${ }^{29 F L 01}{ }^{29}$ For the relationship of the abyss with the womb and the use of the verb "to give birth" related to the sea, 29FL 02 see above.

${ }_{30 \mathrm{FL} 01}{ }^{30}$ In Old Babylonian Ur is Ningal, the spouse of the moon god Sin, who protects the seafarers (Oppenheim 30FL02 1954). 
north and the interior of the plain. Urbanisation and political power move upstream, following the Tigris and the Euphrates, leading to the pre-eminence of centres settled in the region north of Sumer, Agade. The first enduring unification of the region is undertaken by the kings of Agade (ca. XXIV cent. BCE), a kingdom whose capital (Agade) lay on the centre of the Southern Mesopotamian plain. ${ }^{31}$ After the fall of the Akkadian dynasty, the Sumerian city-states occasionally regain independence or political control over the region. The last Mesopotamian kingdom of the third millennium has its capital in the southern city of Ur (Ur III dynasty, XXI cent. BCE), but the political and strategic scenario is no longer the Persian Gulf. Military and commercial activities are now mainly directed towards the Iranian plateau, Anatolia, Syria, and the Mediterranean regions. The literature celebrates the wars of Enmerkar, the king of Uruk, against Aratta, a city located in the eastern mountains, as well as the campaigns of Sargon of Agade in Anatolia. Royal inscriptions extensively record the periodic campaigning of Mesopotamian kings attempting to control the areas of production, trading routes, and hubs.

The development of the archaeological investigations in the Gulf has shed light on the development of the cultures and economies of these areas and their relationships with Mesopotamia. However, the archaeological and epigraphic evidence from Mesopotamia remains scanty. The few cuneiform evidences have been available for decades and have not increased in quantity or quality in recent years. They provide no clear clues on the nature of these relationships. They are few, vague, and thus subject to different interpretations by modern scholars. ${ }^{32}$

In fact, in administrative texts and royal inscriptions, references to the sea are even scarcer than in literature. Administrative texts record quantities of goods as well as boats, officials, and persons related to the overseas lands of Dilmun, Magan, and Meluhha. In comparison with the total amount of documents known for an archive or a historical period, administrative texts related to overseas trade are infinitesimally few; the quantities of goods or boats they record, on the other hand, being occasionally exceptional in number, raise doubt about the interpretation of the data.

In royal inscriptions, the sea is mentioned occasionally and twofold, always in spatial references. It is a political border and an empty space across which lie exotic countries which provide essential precious goods (stone, metal, wood) and with which Mesopotamians maintain alternate relationships along the third millennium BCE.

The earliest reference to the Gulf in a royal inscription can be dated back to the XXV cent. BCE. Ur-Nanše, the founder of the First dynasty of Lagaš, mentions Dilmun in a sentence that appears in several of his inscriptions, "(Ur-Nanše) made the boat of Dilmun to bring timber from the mountain (or: the foreign country) to the shore (of Sumer/Lagaš)" ${ }^{33}$ The words of Ur-Nanše sound like a foundation act, at least in the perspective of the king. It is he who made the boats of Dilmun bring timber to Lagaš, suggesting that this has not been done before or, at least, that when he became king this was not the norm. We know from archaeological sources that this is not the case, but this kind of statement will become

\footnotetext{
31FL01 31 The site of the ancient city of Agade has not been identified; it is believed to lay somewhere between 31FL02 Baghdad and Babylon.

32FL01 ${ }^{32}$ Compare, for instance, the collected essays edited by Potts (1983) and the review of this work by How32FL02 ard-Carter (1987), as well as the article on the Persian Gulf by Heimpel (1987) and the recent synthesis by ${ }^{32}{ }^{2} 03$ Laursen and Steinkeller (2017); the latter provides an almost complete bibliography on the topic.

${ }_{33 \mathrm{FL} 01}{ }^{33} \mathrm{ma}_{2}$-dilmun kur-ta gu ${ }_{2}$ gišs mu-ĝal ${ }_{2}$; see Heimpel (1987). This sentence (see also fn. 9) has been alter33FL02 natively translated as "he made the ships of Dilmun to submit themselves to him (to deliver goods) from 33FL03 (their) land", see Laursen and Steinkeller (2017).
} 
frequent in royal inscriptions of the successive periods. Recalling Ur-Nanše's sentence or using other words, later kings celebrate the success of making the boat of Dilmun, Magan, and Meluhha mooring at the quay of the Mesopotamian cities or of subduing these regions and making them providing goods. This periodical reference to re-establishing contacts with overseas countries reveals the unstable relationship with the Gulf partners, at least as regards royal control.

The record of successful overseas military campaigns documented in royal inscriptions of the Agade kings (ca. XXIV cent. BCE) and their successors should be considered in the same light. These are very few, particularly compared with the inland campaigns against Elam, northern Mesopotamia, and Syria. Isolated and ephemeral, the overseas exploits of Mesopotamian kings are described with the enrichment of exotic details and heroic deeds that marks their exceptionality. Sargon claims in an inscription that « he moored the ships of Meluhha, Magan, and Dilmun at the quay of Agade» (RIME 2.1.1.12 and 28). ${ }^{34}$ After him, Maništusu crossed the Lower Sea and, after the defeat of a coalition of "thirty-two cities", «quarried the black stone of the mountains across the Lower Sea, loaded (it) on ships, and moored (the ships) at the quay of Agade» (RIME 2.1.3.1). His successor, Naram-Sin conquered Magan, defeated his ruler (Manium) and «in their mountains he quarried diorite stone and brought it to Agade, his city» (RIME 2.1.4.13). This means that in a period of ca. fifty years between the beginning of Maništusu's reign and Naram-Sin's, two successive campaigns were led against overseas countries to provide stone to Mesopotamian rulers. With regards to Sargon's claim that he made the boats of Meluhha, Magan and Dilmun mooring at Agade's quay, the exploits of Maništusu and Naram-Sin reveal that they had recourse to a violent act instead of a regular and peaceful exchange. Furthermore, their campaigns are a failed attempt to control the production area or trading posts.

Economic documents corroborate the idea of irregular contact between Mesopotamia and the Gulf in central administration archives. ${ }^{35}$ The earliest reliable evidence is in the Early Dynastic (ca. XXV-XXIV cent. BCE) sources, where only Dilmun is mentioned among the overseas commercial partners. This confirms the antiquity and prestige of Dilmun, whose mythical status is often referenced in Sumerian literature, besides the foundation by Enki celebrated in Enki and Ninhursaĝa. Except for Ur-Nanše's, Dilmun does not appear in other royal inscriptions of this period, but it is frequent in administrative records, particularly from Ĝirsu, ${ }^{36}$ where the term dilmun qualifies different types of goods, and it appears occasionally in personal names (amar-dilmun-na ${ }^{\mathrm{ki}}$, dilmun-ĝ $\mathrm{g}_{10}$, lugal-sa $\hat{\mathrm{g}}$-dilmun) or professions (gal-dilmun). ${ }^{-37}$ In the Old Akkadian period (ca. XXIV cent. BCE), references to

\footnotetext{
${ }_{34 \mathrm{FL} 01}{ }^{34}$ In a later Akkadian composition celebrating the great revolt against Naram-Sin, the latter claims that 34FL02 before him, Sargon crossed the sea, defeated Magan and «washed his weapon in the Lower Sea» (Wilcke 34FL03 1997).

35FL01 ${ }^{35}$ These data have been interpreted differently by other scholars. For example, Carter (2013) quotes the few 35FL02 administrative records as evidence for intense and continuous exchange relationship between Mesopotamia ${ }^{35 F L 03}$ and the Persian Gulf.

36FL01 ${ }^{36}$ See in general Heimpel (1987) for the references to the boats arriving to or departing to Dilmun and to 36FL02 the goods traded. The ideogram DILMUN appears several times in Early Dynastic documents from Ur (ca. ${ }^{36 \mathrm{FL} 03} \mathrm{XXVI}$ cent. BCE); in some cases, it seems to be part of a personal name, but in other cases the fragmentary ${ }^{36 \mathrm{FL} 04}$ state of conservation of the tablet or the obscure meaning of the text does not allow a proper interpretation.

37FL01 ${ }^{37}$ The administrative documents record an apprentice (dumu gal-dilmun, WF 142: obv. ii 6) as well. The 37FL02 gal-dilmun appears in line 51 of the Early Dynastic list of officials, preceded by kuš /šuš $_{3}$ "(a profession or ${ }_{37 F L 03}$ title)" and followed by šidim "carpenter". The term dilmun alone is found in the Early Dynastic $\mathrm{Lu}_{2} \mathrm{E}$ list ${ }^{37 F L 04} 41$, between the potter $\left(\right.$ bahar $\left._{2}\right)$ and the boat-builder $\left(\mathrm{ma}_{2}-\mathrm{gin}_{2}\right)$.
} 
Dilmun are drastically reduced. A dozen documents from different Sumerian cities record boats, merchants, and people of Dilmun, but Magan and Meluhha appear for the first time in the same quantity. This is parallel to the first mentions of Magan and Meluhha in Akkadian kings' inscriptions. The Neo-Sumerian administrative documents of the end of the third millennium BCE give a clear idea of the development of the relationship of Mesopotamia with the Gulf. Among the ca. 95.000 Neo-Sumerian documents we have only 10 references to Dilmun, ca. 55 to Meluhha, ca. 50 to Magan. These meagre results show firstly the absence of a constant and continued relationship of the Ur III state with the Gulf partners, and secondly the eventual loss of importance of Dilmun on behalf of the other two regions.

In royal ideology, the sea becomes soon the limit of the world. The expression introduced by Lugalzagesi (XXIV cent. ca.), from "the lower sea to the upper sea" is adopted by the successive rulers together with other expressions such as "reaching the seashore" or "cleaning the weapons in the sea" as a final act of a military campaign that has reached the limit of the world.

From the mid third millennium BCE, the centre of power and the urbanisation shift to the north. The cities of Kiš and Agade, located in the area north of Sumer (Agade), are the seat of the kings who control the region. The settlements develop in the same region, while those of Sumer decrease. Despite criticisms (Powell 1985), overexploitation of agriculture and salinization of the soil have traditionally been claimed as reasons for the crisis of Southern Mesopotamia (Jacobsen 1982; Altaweel 2018). The urbanisation of the coastal area collapses by the end of the third millennium BCE, after which the area is deurbanised. The main cities of Sumer fall and are abandoned (Umma, Girsu, Adab), or survive only as cultic centres (Nippur, Eridu, Ur). The collapse of urbanisation leads to a power vacuum, which involves the abandonment of the maintenance of the centralised system of canals; the area returns to marshes. The centres of power now settled in the north are unable toor not interested in the-control (of) this area. "Wild" and uncontrolled, the coastal region becomes a periphery and an obstruction to access the Persian Gulf.

\section{Conclusions}

The historical development of the region during the third millennium BCE determines the scarcity of references to the sea in written sources. These reflect a general and increasing loss of importance of the sea between the mid third millennium, when the Persian Gulf is still the strategic focus, and the end of the millennium, when the coastal area is abandoned and almost inaccessible to urban states. Despite the limited references, the image of the sea in Sumerian literature is well defined. Wide, vast, and empty, the sea is celebrated for its force and the fear it inspires. The towering waves, the mighty tide, and the irresistible flood are synonyms and metaphors of awesomeness and terror as well as of overpowering forces. Rather than a space of communication that can be crossed and through which different lands are in contact, the sea is a space of delimitation, a natural, political, and mythological border. Its geography is vague. Its vastness is a parameter for spatial extension. Its "centre" is the most remote place, unknown and unfathomable, even for the gods. The lands that lie across the sea are exotic, almost mythical. Female engendered, the sea produces its abundant yield by itself. Finally, several elements relate the sea with the Kur and the realm of death. The sea, or the "salty" river, as a water border which divides the land of the living and the land of the dead is an idea suggested by Sumerian literary passages and will be fully developed in the successive Akkadian tradition. In short, the sea is depicted as an unfamiliar and alien element in the Sumerian literary sources. 


\section{References}

Altaweel M (2018) Water management across time: Dealing with too much or too little water in ancient Mesopotamia. In: Zhuang Y, Altawell M (eds) Water societies and technologies from the past and present. UCL Press, London, pp 180-199

Barjamovic G (2018) Interlocking commercial networks and the infrastructure of trade in western Asia during the Bronze Age. In: Kristiansen K, Lindkvist T, Myrdal J (eds) Trade and civilisation: Economic networks and cultural ties, from prehistory to the early modern era. Cambridge University Press, Cambridge, pp 113-113

Carter R (2013) The Sumerians and the Gulf. In: Crawford H (ed) The Sumerian world. Routledge, London, pp 579-599

Edzard DO (1993) Meer. Mesopotamien. Reallexikon der Assyriologie 8(1-2):1-3

Frayne DR (1993) The Royal Inscriptions of Mesopotamia, Early Periods. 2: Sargonic and Gutian periods, 2334-2113 BC. University of Toronto Press, Toronto

George AR (1993) House most high: The temples of ancient Mesopotamia. Eisenbrauns, Winona Lake

Heimpel W (1987) Das Untere Meer. Zeitschrift für Assyriologie 77:22-91

Heimpel W (1998) Nanše. Reallexikon der Assyriologie 9(1-2):152-160

Horowitz W (1998) Mesopotamian Cosmic Geography. Eisenbrauns, Winona Lake

Howard-Carter T (1987) Dilmun: at sea or not at sea? A review article. J Cuneiform Stud 39:54-117

Jacobsen T (1982) Salinity and irrigation agriculture in antiquity Diyala basin archaeological projects. Undena Publications, Malibu

Katz D (2003) The Image of the Netherworld in the Sumerian Sources. CDL Press, Bethesda

Kramer SN (1977) Commerce and trade: Gleanings from Sumerian literature. Iraq 39:59-66

Laursen S, Steinkeller P (2017) Babylonia, the Gulf Region and the Indus: Archaeological and textual evidence for contact in the third and early second millennia BC. Eisenbrauns, Winona Lake

Liverani M (2013) The Ancient Near East: history, society and economy. Routledge, London

Maekawa K, Mori W (2011) Dilmun, magan and meluhha in early mesopotamian history: 2500-1600 BC. In: Osada T, Witzel M (eds) Cultural relations between the Indus and the Iranian Plateau during the third millenium BCE. Harvard University, Cambridge, pp 245-269

Maiocchi M (2005) Sul valore ponderale del siclo "DILMUN" nei testi di Ebla. Kaskal 2:43-53

Marchesi G (2014) Tilmun (Dilmun). Reallexikon der Assyriologie 14:50-52

Nissen HJ (1988) The early history of the ancient near east, 9000-2000 B.C. The University of Chicago Press, Chicago

Oppenheim AL (1954) The Seafaring Merchants of Ur. J Am Orient Soc 74:6-17

Pettinato G (1972) Il commercio con l'estero della Mesopotamia meridionale nel 3. millennio av. Cr. alla luce delle fonti letterarie e lessicali sumeriche. Mesopotamia 7:43-166

Potts DT (ed) (1983) Dilmun. New studies in the archaeology and early history of Bahrain. Dietrich Reimer Verlag, Berlin

Potts DT (1997) Mesopotamian civilization: the material foundations. Cornell University Press, Ithaca

Potts DT (2009) Maritime Trade I. Pre-Islamic Period. Encyclopedia Iranica Online. https://www.iranicaonl ine.org/articles/maritime-trade-i-pre-islamic-period. Accessed 7 Aug 2019

Pournelle J (2003) Marshland of cities: deltaic landscapes and the evolution of early Mesopotamian civilization. University of California, San Diego

Powell M (1985) Salt, seed, and yields in sumerian agriculture. A critique of the theory of progressive salinization. Zeitschrift für Assyriologie 75:7-38

Safar F, Mustafa MA, Lloyd S (1981) Eridu. State Organization of Antiquities and Heritage, Baghdad

Sallaberger W, Schrakamp I (eds) (2015) Associated regional chronologies for the ancient near east and the eastern mediterranean, III. History \& philology. Brepols, Turnhout

Steinkeller P (2013) Trade routes and commercial networks in the Persian Gulf during the third millennium BC. In: Faizee C (ed) Collection of papers presented to the third international biennial conference of the Persian Gulf. University of Tehran Press, Teheran, pp 413-431

Verderame L (2011) L'immagine della città nella letteratura sumerica. In: Dolce R, Pellitteri A (eds) Città nel Vicino Oriente e nel Mediterraneo. Flaccovio, Palermo, pp 99-126

Verderame L (2014) Aspetti spaziali nella costruzione dell'immaginario infero dell'antica Mesopotamia. SMSR 80:23-41

Verderame L (2020a) Noisy city, silent steppe, tweeting marsh. Soundscapes in Sumerian literature. In: Nadali D, Pinnock F (eds) Sensing the past: detecting the use of the five senses in Ancient Near Eastern contexts. Harrassowitz, Wiesbaden, pp 85-99 
Verderame L (2020b) Engendered Cosmic Spaces in Ancient Mesopotamian Myths. In: Alpert Nakhai B, De Graef K, Garcia-Ventura A, Goddeeris A (Eds.), Proceedings of the Third Workshop on Gender, Methodology and the Ancient Near East (GeMANE 3; Ghent, 2019). Zaphon, Münster (forthcoming) Wilcke C (1997) Amar-girids Revolte gegen Narām-Su'en. Zeitschrift für Assyriologie 87:11-32

Publisher's Note Springer Nature remains neutral with regard to jurisdictional claims in published maps and institutional affiliations. 